\title{
Caracterización de la curva de lactancia de bovinos Siboney con modelos no lineales mixtos
}

\section{Characterization of lactation curves in Siboney cattle using nonlinear mixed models}

\author{
Alejandro Palacios-Espinosaa, J oel Domínguez-Viverosb, Yamariz Padrón-Quinteroc, \\ Manuel Rodríguez Castroc, Felipe Alonso Rodríguez-Almeidab, J osé Luis Espinoza-Villavicencioa, \\ Narciso Ysac Ávila-Serranod
}

\begin{abstract}
RESUMEN
En bovinos productores de leche la curva de lactancia (CL) se ha analizado con modelos no lineales (MNL), y recientemente se ha implementado la metodología de MNL mixtos. Los objetivos fueron: a) ajustar un MNL a la CL a 240 días; b) comparar MNL vs MNL mixtos; c) estimar producción al pico (PMAX) y total a 240 días (PTOTAL), así como días para alcanzar la producción máxima (DPMAX). Se analizaron 15,324 observaciones de producción diaria (kg), correspondientes a primera lactancia de 2,809 vacas Siboney, con fecha de parto de 2000 a 2012 en 28 hatos en Cuba. Se evaluaron cinco MNL: Wood, Wiltmink, Cobby, Brody y Sikka. Se realizaron dos análisis con el procedimiento NLMIXED de SAS: ANA1, incluyó sólo el efecto aleatorio de los residuales; y ANA2, incluyó el efecto aleatorio correspondiente a un coeficiente de regresión, más los residuales. La selección del modelo con mejor ajuste se realizó con: error de predicción promedio; varianza del error de predicción; estadístico Durbin Watson; coeficiente de determinación ( $\left.R^{2}\right)$; criterios de información Akaike (AIC) y Bayesiano (BIC). Los MNL mixtos mostraron el mejor ajuste con base en: a) los $R^{2}$ del ANA2 fueron superiores, en un intervalo de 9 a $12 \%$; b) por la reducción en la varianza residual en el ANA2; y, c) los criterios AIC y BIC, mostraron mejor ajuste en los MNL del ANA2. EI modelo de mejor ajuste en todo el estudio fue WOD del ANA2, con estimaciones para PMAX, DPMAX y PTOTAL de 7.71 kg, 40 días y 1,653 $\mathrm{kg}$, respectivamente.
\end{abstract}

PALABRAS CLAVE: Bovinos leche, Cruzamiento, Raza sintética, Ganadería tropical, Modelos no lineales.

\begin{abstract}
Nonlinear models (NLM) have been used to evaluate dairy cattle lactation curves (LC), and nonlinear mixed models are increasingly applied. The most appropriate model for estimating LC components in Siboney cattle was identified by applying a NLM for LC to 240 d; comparing a non-mixed NML vs a mixed NML; and estimating peak production (PMAX), total production at 240 d (PTOTAL) and days to maximum production (DPMAX). The database consisted of 15,324 records for daily milk production $(\mathrm{kg})$ corresponding to first lactation in 2,809 Siboney cows (calving date in 2000-2012) in 28 herds in Cuba. Five NLM were evaluated: Wood, Wiltmink, Cobby, Brody and Sikka. Two SAS NLMIXED analyses were run: ANA1, including only the random effect of residuals; and ANA2, including a regression coefficient random effect plus residuals. Selection of the best fitting model was done based on average prediction error; prediction error variance; the Durbin Watson statistic; the determination coefficient $\left(R^{2}\right)$; the Akaike information criterion (AIC); and the Bayesian information criterion (BIC). The mixed NLM (ANA2) had the best fit: a) its $R^{2}$ was higher (9 to $12 \%$ ); b) residual variance was notably reduced; and c) the AIC and BIC criteria exhibited a better fit. The model with the overall best fit was the ANA2 WOD, with estimates of $7.71 \mathrm{~kg}$ for PMAX, $40 \mathrm{~d}$ for DPMAX and 1,653 $\mathrm{kg}$ for PTOTAL.
\end{abstract}

KEY WORDS: Dairy cattle, Crossbreeding, Synthetic breed, Tropical livestock, Milk production, Nonlinear models.

Recibido el 1 de agosto de 2014. Aceptado el 17 de septiembre de 2014.

a Departamento de Zootecnia, Universidad Autónoma de Baja California Sur. La Paz, Baja California Sur. México.

b Facultad de Zootecnia y Ecología, Universidad Autónoma de Chihuahua. Periférico Francisco R. Almada km 1, 31453, Chihuahua, Chihuahua, México; Tel (614)4341448.jodominguez@uach.mx joeldguezviveros@yahoo.com.mx. Correspondencia al segundo autor.

c Centro de Investigaciones para el Mejoramiento Animal de la Ganadería Tropical. La Habana, Cuba.

d Instituto de Recursos, Universidad del Mar. Puerto Escondido, Oaxaca. México. 
El mejoramiento genético para incrementar la producción de leche en las regiones tropicales de climas cálidos se ha fundamentado, entre otras estrategias, en las cruzas de razas adaptadas ( $\mathrm{Bl}$; Bos indicus) con razas especializadas de climas templados y fríos (BT; Bos taurus), aprovechando las ventajas del cruzamiento en diversos grados de encaste(1). En Cuba, a partir de los años 60 del siglo $X X$, se iniciaron cruzamientos entre Holstein y Cebú con el objetivo de obtener genotipos aptos para producir leche y adaptados a las condiciones tropicales de ambientes adversos; como resultado se generaron dos razas sintéticas $(2,3)$, Siboney (5/8 Holstein y 3/8 Cebú) y Mambí (3/ 4 Holstein y $1 / 4$ Cebú). Con respecto a Siboney, surgió como parte del Programa Nacional de Mejoramiento Genético para obtener genotipos menos exigentes que el Holstein, que desarrollaran un adecuado potencial productivo en condiciones tropicales con alimentación basada fundamentalmente en el pastoreo $(4,5)$.

Para caracterizar la producción de leche en bovinos, la curva de lactancia (CL) se analiza a través de tres periodos, con cuatro componentes principales: 1) producción inicial; 2) fase ascendente o de incremento de la producción; 3) punto máximo o pico de producción; y, 4) tasa descendente o reducción de la producción, denominada persistencia $(6,7,8)$. En la caracterización y análisis de la $\mathrm{CL}$ se han utilizado modelos no lineales (MNL), donde los coeficientes de regresión tienen una interpretación asociada a los estadios de la CL, o permiten derivar otros indicadores que describen la $\mathrm{CL}^{(9,10)}$. El ajuste de los MNL se ha realizado con el análisis de regresión no lineal, utilizando métodos iterativos como Gauss, Marquardt y Newton, entre otros(11). Desde el punto de vista estadístico, la producción de leche con mediciones a través de la lactancia, representa un caso particular de medidas repetidas en el tiempo, generando una estructura de varianzas y covarianzas que puede ser analizada con modelos mixtos $(12,13)$ con efectos positivos en los análisis para el ajuste de MNL. Los análisis de regresión no lineal,
Genetic improvement aimed at increasing milk production in warm tropical regions is based, among other strategies, on crosses between adapted breeds (BI; Bos indicus) and specialized breeds from temperate and cold climes (BT; Bos taurus). Different degrees of crossbreeding provide different advantages(1). Beginning in the 1960s, crossbreeding began between the Holstein and Zebu breeds in Cuba with the aim of developing genotypes apt for milk production and adapted to adverse tropical conditions. Two synthetic breeds resulted(2,3): Siboney $(5 / 8$ Holstein + 3/8 Zebu) and Mambí (3/4 Holstein $+1 / 4$ Zebu). The Siboney breed was created as part of the National Genetic Improvement Program to produce genotypes less demanding than Holstein that could attain adequate production potential under tropical conditions with feeding based mainly on grazing $(4,5)$.

The lactation curve (LC) is used to analyze dairy cow milk production in three periods with four main components: 1) initial production; 2) increased production or ascending phase; 3) maximum production or peak phase; and 4) descending rate or reduced production, called persistence $(6,7,8)$. Nonlinear models (NLM) have been used to characterize and analyze LCs. In this approach, regression coefficients are interpreted in association with LC stages, or help to derive other indicators that describe the $L C(9,10)$. Adjusting NLM has been done using nonlinear regression analysis involving iterative methods such as those of Gauss, Marquardt and Newton, among others(11). Statistically analyzing milk production through lactation measurements involves repeated measurements over time. This generates a variance/covariance structure that can be analyzed using mixed models $(12,13)$, with positive effects in NLM fit analyses. Nonlinear regression analyses, including random effects related to the regression coefficients, are run using a different iterative method (e.g. Firo, Gauss, Hardy and Isamp) $(14,15)$ than used in NLMs with only fixed effects.

Understanding LC is important for dairy cattle management, feed and genetic improvement 
integrando efectos aleatorios relativos a los coeficientes de regresión, se realizan a través de método iterativo diferente (Firo, Gauss, Hardy e I samp) $(14,15)$ a los utilizados en los MNL con sólo efectos fijos.

El conocimiento de la $\mathrm{CL}$ permite orientar programas de manejo, alimentación y mejoramiento genético(16). En sistemas de producción intensivos o estabulados, con razas especializadas como Holstein, el análisis de la CL se realiza a 305 días en leche; sin embargo, en los sistemas de producción tropicales, dado los efectos ambientales y las condiciones de manejo con repercusiones en la vida productiva de la vaca, la definición, análisis y caracterización de la lactancia se realiza a intervalos menores, como es el caso de 210 o 240 días $(17,18,19)$. Para caracterizar y analizar la $\mathrm{CL}$ de bovinos Siboney, los objetivos del presente estudio fueron: a) seleccionar un MNL que se ajuste a la $\mathrm{CL}$ de bovinos Siboney; b) comparar los procedimientos de regresión no lineal, con MNL de solo efectos fijos vs MNL mixtos; c) estimar componentes o indicadores de la $\mathrm{CL}$, con el modelo no lineal de mejor ajuste.

La base de datos fue proporcionada por el Centro de Investigaciones para el Mejoramiento Animal de la Ganadería Tropical, dependiente del Ministerio de Agricultura de la República de Cuba. Se analizaron 15,324 observaciones de producción diaria de leche $(\mathrm{kg})$, en el intervalo de 1 a 240 días, de primeras lactancias en 2,809 vacas Siboney, con partos ocurridos de enero de 2000 a diciembre de 2012. Los datos provinieron de 28 hatos manejados en un sistema de pastoreo, ubicados entre los 20 y $23^{\circ} \mathrm{N}$, y 74 y $85^{\circ} \mathrm{O}$, con dos estaciones claramente definidas; la de lluvias de mayo a octubre, en la que ocurre del 70 al $80 \%$ de la precipitación, y la estación seca de noviembre a abril; la temperatura media anual es de 23.1 ${ }^{\circ} \mathrm{C}$ y la humedad relativa de 60 a $70 \%$ durante el día y de 80 a $90 \%$ durante la noche(20). Para analizar y caracterizar la $\mathrm{CL}$ se evaluaron cinco $\operatorname{MNL}(7,9,21)$ : programs(16). Analysis of LC is done at $305 \mathrm{~d}$ lactation in intensive or corral production systems with specialized breeds such as Holstein. However, the environmental effects and handling conditions in tropical production systems shorten cow productive life, and as a consequence the definition, analysis and characterization of lactation is done over shorter intervals, from 210 to $240 \mathrm{~d}(17,18,19)$. In an effort to characterize and analyze the Siboney cattle LC, the present study objectives were to a) select a NLM that fits the Siboney LC; b) compare nonlinear regression procedures for the only fixed effects NLM versus the mixed $\mathrm{NLM}$; and c) use the NLM with the best fit to estimate LC components or indicators.

The data analyzed in this study were from the data base of the Research Center for Genetic Improvement of Tropical Livestock (Centro de Investigaciones para el Mejoramiento Animal de la Ganadería Tropical), a division of the Ministry of Agriculture of the Republic of Cuba. A total of 15,324 daily milk production $(\mathrm{kg})$ records were analyzed, in an interval of 1 to $240 \mathrm{~d}$, for first lactations in 2,809 Siboney cows that had given birth between J anuary 2000 and December 2012. These data were collected from 28 herds located on the island of Cuba (20 and $23^{\circ} \mathrm{N}, 74$ and $85^{\circ} \mathrm{W}$ ) and managed using a grazing system. The island experiences two clear seasons, a rainy season from May to October during which 70 to $80 \%$ of rainfall occurs, and a dry season from November to April. Mean annual temperature is $23.1{ }^{\circ} \mathrm{C}$ and average relative humidity ranges from 60 to $70 \%$ in the day to 89 to $90 \%$ at night $(20)$.

Five NLMs were evaluated for their effectiveness in analyzing and characterizing $\operatorname{LC}(7,9,21)$ :

1) Wood (WOD; $\left.y_{t}=\beta_{1} *\left(t^{\beta 2}\right) *\left(\exp \left(-\beta_{3} * t\right)\right)+\varepsilon_{i j}\right)$

2) Wiltmink (WL; $y_{t}=\beta_{1}+\beta_{2} * t+\beta_{3} *(\exp (-0.05 * t))$ $\left.+\varepsilon_{\mathrm{ij}}\right)$

3) Cobby $\left(\mathrm{COB} ; \mathrm{y}_{\mathrm{t}}=\beta_{1}-\beta_{2} * \mathrm{t}-\beta_{1} *\left(\exp \left(-\beta_{3} * \mathrm{t}\right)\right)+\varepsilon_{\mathrm{ij}}\right)$ 
1) Wood (WOD; $\left.y_{t}=\beta_{1} *(+\beta 2) *\left(\exp \left(-\beta_{3} * t\right)\right)+\varepsilon_{i j}\right)$

2) Wiltmink ( $M L ; y_{t}=\beta_{1}+\beta_{2}{ }^{*} t+\beta_{3}{ }^{*}(\exp (-0.05 * t))$ $\left.+\varepsilon_{i j}\right)$

3) Cobby (COB; $\left.y_{t}=\beta_{1}-\beta_{2} * t-\beta_{1} *\left(\exp \left(-\beta_{3} * t\right)\right)+\varepsilon_{i j}\right)$

4) $\operatorname{Brody}\left(B R O ; y_{t}=\beta_{1} *\left(\exp \left(-\beta_{2} * t\right)\right)-\beta_{1} *\left(\exp \left(-\beta_{3}{ }^{*} \mathrm{t}\right)\right)\right.$ $\left.+\varepsilon_{\mathrm{ij}}\right)$

5) Sikka $\left(S I K ; y_{t}=\beta_{1} *\left(\exp \left(\left(\beta_{2}{ }^{* t}\right)-\left(\beta_{3}{ }^{*} 2\right)\right)\right)+\varepsilon_{i j}\right)$

Donde: $y_{t}=$ corresponde a la producción de leche $(\mathrm{kg})$ en el día $\mathrm{t}(1$ a 240$) ; \beta_{1}, \beta_{2}$ y $\beta_{3}=$ son los coeficientes de regresión que componen cada modelo; y $\varepsilon_{\mathrm{ij}}$ son los efectos aleatorios, asociados a los errores o residuales, de la j-ésima producción en el i-ésimo día de lactancia. Posteriormente, a partir de los $\beta$ de cada modelo, se estimó la producción al inicio de la lactancia (PI), días para alcanzar la producción máxima (DPMAX), producción al pico o máxima (PMAX), y la producción total (PTOTAL) o acumulada a 240 días de lactancia, como

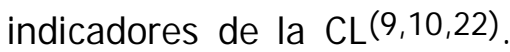

Se realizaron dos análisis con el procedimiento NLMIXED de SAS, utilizando el método iterativo de Gauss (13,23): 1) MNL sin incluir efectos aleatorios relacionados con los coeficientes de regresión, sólo el efecto aleatorio $(\varepsilon)$ de los residuales (ANA1); y, 2) MNL mixtos, se agregó el efecto aleatorio correspondiente al $\beta_{1}$ de cada modelo, más los residuales (ANA2). Los efectos aleatorios, no correlacionados, de $\varepsilon_{i j}$ y $\beta_{1}$ se ajustan a las suposiciones de una distribución normal, con media igual a cero y varianzas de $\sigma^{2}$ y $\sigma^{2} \beta_{1}$, respectivamente; no se incluyeron los efectos aleatorios de los coeficientes de regresión $\beta_{2}$ y $\beta_{3}$, dado que sus componentes de varianza son de muy baja magnitud, y tienden a cero. La selección del modelo con mejor ajuste se realizó en función de seis criterios $(24,25,26)$ :

1) El error de predicción promedio

$$
\left[E P P=\left(\sum_{\mathrm{i}=1}^{\mathrm{n}}\left(\frac{\mathrm{pei}-\mathrm{pmi}}{\mathrm{pmi}}\right) * 100\right) / \mathrm{n}\right] \text {; }
$$

4) Brody (BRO; $y_{t}=\beta_{1} *\left(\exp \left(-\beta_{2} * t\right)\right)-\beta_{1} *\left(\exp \left(-\beta_{3} * t\right)\right)$ $\left.+\varepsilon_{i j}\right)$

5) Sikka $\left(\operatorname{SIK} ; y_{\mathrm{t}}=\beta_{1}{ }^{*}\left(\exp \left(\left(\beta_{2}{ }^{*}\right)-\left(\beta_{3}{ }^{*}+2\right)\right)\right)+\varepsilon_{i j}\right)$

Where: $y_{t}$ is milk production $(\mathrm{kg})$ on day $\mathrm{t}(1$ to 240); $\beta_{1}, \beta_{2}$ and $\beta_{3}$ are each model's regression coefficients; and $\varepsilon_{\mathrm{ij}}$ are random effects, associated with errors or residuals, of $\mathrm{j}$-th production on the i-th day of lactation. Four LC indicators were estimated using each model's $\beta$ values: lactation initial production (IP); days to maximum production (DPMAX); peak or maximum production (PMAX); and total or accumulated production (PTOTAL) at $240 \mathrm{~d}$ lactation $(9,10,22)$.

Two analyses were run with the NLMIXED procedure in the SAS program, using the Gauss iterative $\operatorname{method}(13,23)$ : 1) a NLM without random effects related to the regression coefficients and only the random effect $(\varepsilon)$ of the residuals (ANA1); and 2) a mixed NLM in which the random effect of each model's $\beta_{1}$ was added to the residuals (ANA2). The noncorrelated random effects of $\varepsilon_{\mathrm{ij}}$ and $\beta_{1}$ fit the assumptions of a normal distribution, with a mean equal to zero and variances of $\sigma^{2} \mathrm{e}$ and $\sigma^{2} \beta 1$, respectively. The random effects of the regression coefficients $\beta_{2}$ and $\beta_{3}$ were not included because their variance components were very low magnitude and tended towards zero. Selection of the best fit model was done based on six criteria $(24,25,26)$ :

1) Average prediction error

$\left[A P E=\left(\sum_{\mathrm{i}=1}^{\mathrm{n}}\left(\frac{\mathrm{epi}-\mathrm{pmi}}{\mathrm{pmi}}\right) * 100\right) / \mathrm{n}\right]$;

2) Prediction error variance:

$\left[\mathrm{PEV}=\sum_{\mathrm{i}=1}^{\mathrm{n}}(\mathrm{pmi}-\mathrm{epi})^{2} / \mathrm{n}\right]$;

3) Durbin Watson statistic

$\left[D W=2(1-\tilde{n}) ; \rho=\frac{\sum_{t=2}^{n}\left(e_{t}-e_{t-1}\right)^{2}}{\sum_{t=1}^{n} e_{t}^{2}}\right]$;

4) Determination coefficient $\left[R^{2}=(1-(\mathrm{ssr} / \mathrm{tss}))\right]$; 
2) la varianza del error de predicción

[VEP $\left.=\sum_{\mathrm{i}=1}^{\mathrm{n}}(\mathrm{pmi}-\mathrm{pei})^{2} / \mathrm{n}\right]$;

3) el estadístico Durbin Watson

$\left[D W=2(1-\tilde{n}) ; \rho=\frac{\sum_{t=2}^{n}\left(e_{t}-e_{t-1}\right)^{2}}{\sum_{t=1}^{n} e_{t}^{2}}\right]$;

4) el coeficiente de determinación

$\left[R^{2}=(1-(\mathrm{sce} / \mathrm{sct}))\right]$;

5) el criterio de información Akaike [AIC $=-2 *$ Log lik+2k];

6) el criterio de información Bayesiano $[\mathrm{BIC}=-2 *$ Log lik $+\log (\mathrm{n}) * \mathrm{k}]$.

Donde: $p m i=$ producción medida en el i-ésimo día de lactancia; pei= producción estimada para el i-ésimo día de lactancia; $n=$ número total de observaciones; sce= suma de cuadrados de los residuales; sct= suma de cuadrados total; Log lik= logaritmo de la función de verosimilitud; k= número de parámetros en el modelo. El EPP analiza la relación que existe entre la producción medida y la producción estimada para el i-ésimo día de lactancia, y en función del signo, el MNL sobreestima (+) o subestima (-) las predicciones. Para EPP, VEP, AIC y BIC, el modelo con el menor valor se consideró como el de mejor ajuste; a diferencia del $\mathrm{R}^{2}$, el modelo con el valor más alto representa el mejor ajuste. El estadístico DW analiza las auto correlaciones en los errores, con tres planteamientos: a) si $2<D W<4$ existe auto correlación negativa; b) si $0<D W<2$ indica ausencia de auto correlación; y, c) si $D W \leq 0$ indica que existe auto correlación positiva.

En el Cuadro 1, se presentan los resultados de los criterios estadísticos para la selección del modelo de mejor ajuste; para EPP, VEP y DW los resultados son similares a través de los dos análisis realizados. Con base en el EPP y el estadístico DW, las predicciones de todos los MNL tendieron a subestimar la información analizada, con ausencia de auto correlación entre los residuales. Los MNL mixtos mostraron el mejor ajuste con base en tres resultados del Cuadro 1: a) las varianzas residuales de los
5) Akaike information criterion [AIC $=-2 *$ Log lik+2k];

6) Bayesian information criterion [BIC $=-2 *$ Log lik $+\log (n) * k]$

Where pmi is the production measured on the i-th day of lactation; epi is the estimated production for the $\mathrm{i}$-th day of lactation; $\mathrm{n}$ is the total number of observations; ssr is the sum of squares of residuals; tss is the total sum of

Cuadro 1. Ajuste de modelos no lineales en la caracterización de curvas de lactancia de bovinos Siboney

Table 1. Nonlinear model fit in the characterization of lactation curves in Siboney cattle

\begin{tabular}{|c|c|c|c|c|c|}
\hline Item & WOD & WIL & $\mathrm{COB}$ & BRO & SIK \\
\hline \multicolumn{6}{|c|}{ Nonlinear model fit, not including random effects (ANA1) } \\
\hline$\beta_{1}$ & 5.89 & 8.46 & 8.12 & 8.18 & 7.54 \\
\hline$\beta_{2}$ & 0.0996 & -0.0117 & 0.00953 & 0.00135 & 0.00040 \\
\hline$\beta_{3}$ & 0.00245 & -1.9026 & 0.2676 & 0.2678 & 0.0000073 \\
\hline$\sigma^{2} \mathrm{e}$ & 7.27 & 7.28 & 7.31 & 7.32 & 7.29 \\
\hline AIC & 73916 & 73912 & 73985 & 73997 & 73947 \\
\hline $\mathrm{BIC}$ & 73946 & 73942 & 74016 & 74028 & 73977 \\
\hline $\mathrm{R}^{2}$ & 87.3 & 87.4 & 87.2 & 87.1 & 87.3 \\
\hline APE & -15.7 & -15.6 & -16.3 & -16.2 & -15.9 \\
\hline PEV & 7.28 & 7.28 & 7.33 & 7.33 & 7.29 \\
\hline DW & 1.44 & 1.42 & 1.42 & 1.44 & 1.43 \\
\hline \multicolumn{6}{|c|}{ Nonlinear model fit, including $\beta_{1}$ random effect (ANA2) } \\
\hline$\beta_{1}$ & 6.09 & 8.45 & 8.11 & 8.29 & 7.67 \\
\hline$\beta_{2}$ & 0.0912 & -0.0116 & 0.00951 & 0.00147 & 0.000089 \\
\hline$\beta_{3}$ & 0.00241 & -1.9064 & 0.2677 & 0.2334 & 0.0000062 \\
\hline$\sigma^{2} \mathrm{e}$ & 1.31 & 2.75 & 2.78 & 1.32 & 1.30 \\
\hline$\sigma^{2} \beta 1$ & 4.42 & 4.52 & 4.52 & 8.11 & 7.03 \\
\hline AIC & 73698 & 73906 & 73980 & 73767 & 73732 \\
\hline $\mathrm{BIC}$ & 73736 & 73944 & 74018 & 73805 & 73770 \\
\hline$R^{2}$ & 98.3 & 95.2 & 95.1 & 97.7 & 97.3 \\
\hline APE & -15.7 & -15.5 & -15.8 & -15.8 & -15.7 \\
\hline PEV & 7.28 & 7.27 & 7.31 & 7.32 & 7.30 \\
\hline DW & 1.41 & 1.41 & 1.40 & 1.41 & 1.40 \\
\hline \multicolumn{6}{|c|}{ Lactation curve components } \\
\hline IP & 6.08 & 6.64 & 1.90 & 1.71 & 7.66 \\
\hline DPMAX & 40 & 42 & 20 & 20 & 28 \\
\hline PMAX & 7.71 & 7.74 & 8.03 & 8.04 & 7.60 \\
\hline PTOTAL & 1653 & 1655 & 1667 & 1664 & 1660 \\
\hline
\end{tabular}


MNL del ANA2, fueron menores (hasta $82 \%$ para los modelos de SIK y WOD) a las estimadas en los ANA1; b) por consiguiente, los $\mathrm{R}^{2}$ del ANA2 (96.7 \% en promedio) fueron superiores a los obtenidos en el ANA1 (87\% en todos), en un intervalo de 9 a $12 \%$; c) y conjuntamente, los criterios $\mathrm{AIC}$ y $\mathrm{BIC}$, mostraron mejor ajuste en los MNL del ANA2; posteriormente, dentro del ANA2, el modelo de mejor ajuste fue WOD, seguido de SIK y BRO, en función de los criterios $\mathrm{AIC}, \mathrm{BIC}$ y $\mathrm{R}^{2}$. Las estimaciones de PI, DPMAX, PMAX y PTOTAL se realizaron con los resultados del ANA2 (Cuadro 1). Diferentes autores coinciden en publicar sobre el MNL de WOD, como de mejor squares; Log lik is the likelihood function logarithm; and $k$ is the number of model parameters. The APE analyzes the relationship between measured and estimated production for the i-th day of lactation, and, based on the combination of " + " and "-" signs, the NLM is shown to either over- $(+)$ or underestimate $(-)$ the predictions. For APE, PEV, AIC and BIC, the model with the lowest value is considered that with the best fit. In contrast, for $\mathrm{R}^{2}$ the model with the highest value is considered to have the best fit. The DW statistic analyzes autocorrelations in the errors, using three categories: a) $2<D W<4$ indicates a negative autocorrelation; b) $0<\mathrm{DW}<2$ indicates no

Figura 1. Descripción de la curva de lactancia de bovinos Siboney, ajustada a 240 días con base en los modelos de Wiltmink (a; WIL) y Wood (b; WOD)

Figure 1. Siboney cattle lactation curves adjusted to 240 days based on the Wiltmink ( $a$; WIL) and Wood (b; WOD) models
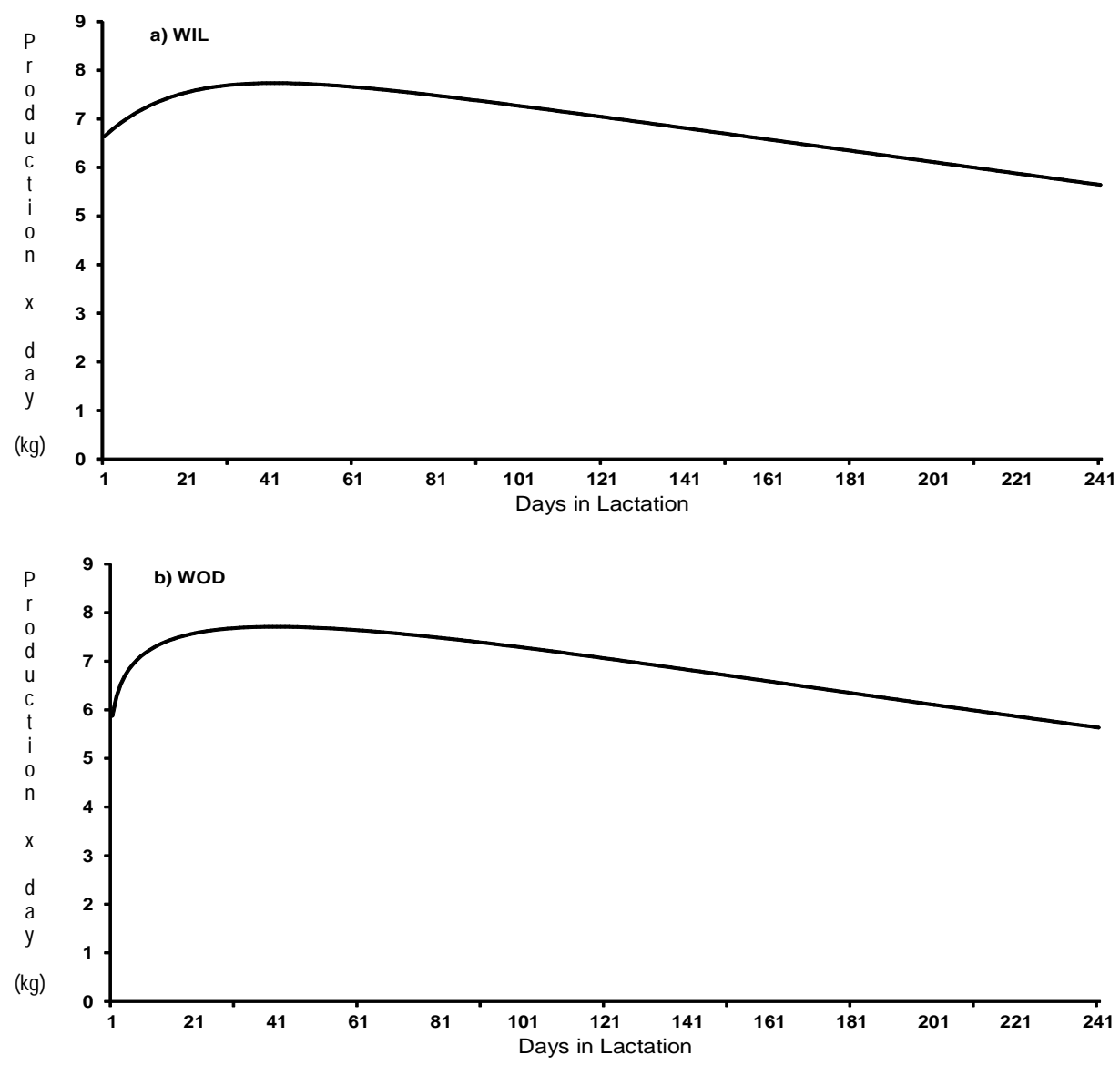
ajuste estadístico a través de diversos criterios de selección o jerarquización, o en su caso más popular, para describir y analizar las $\mathrm{CL}$ de bovinos para leche; los coeficientes de regresión que lo conforman se asocian a diferentes componentes de la $\mathrm{CL}$, y permiten derivar otros indicadores de la producción, parcial o total, a través del tiempo (7,8,27); García-Muñiz et al(21), reportaron que el MNL de WOD resultó el idóneo, a través de $16 \mathrm{MNL}$ evaluados, en $\mathrm{CL}$ de seis genotipos de bovinos cruzados, con diferentes proporciones de BT y BI; así mismo, en bovinos para carne, el modelo de WOD ha resultado apto, con ajuste idóneo, para modelar la producción de leche a través de diferentes esquemas de muestreo $(28,29)$.

Los $\beta_{1}, \beta_{2}$ y $\beta_{3}$ de los MNL están asociados a la producción al inicio de la lactancia, a la fase ascendente hasta la producción máxima, así como a la tasa descendente o persistencia, respectivamente. Dada la combinación de signos en $\beta_{2}$ y $\beta_{3}$, los modelos de WOD y WIL permiten ajustar cuatro tipos de curvas unimodales(30): 1) curva estándar o típica: WOD $+\beta_{2},-\beta_{3}$ y WIL $-\beta_{2},-\beta_{3} ; 2$ ) curva continuamente decreciente (atípica): WOD $-\beta_{2},-\beta_{3}$ y WIL $+\beta_{2},-\beta_{3}$; 3) curva estándar invertida (U): WOD $-\beta_{2},+\beta_{3}$ y WIL $\left.+\beta_{2},+\beta_{3} ; y, 4\right)$ continuamente incrementando: WOD $+\beta_{2},+\beta_{3}$ y WIL $-\beta_{2},+\beta_{3}$. En la Figura 1 se presenta la CL estándar o típica con base en el modelo de WIL, y la CL continuamente incrementando con el modelo de WOD. Las estimaciones de los componentes de la $\mathrm{CL}$, a través de los MNL evaluados, fueron similares para PMAX y PTOTAL, y con marcadas diferencias para PI y DPMAX (Cuadro 1). Los modelos de $\mathrm{COB}$ y $\mathrm{BRO}$, expresaron valores subestimados para puntos iníciales de la lactancia, como es el caso de PI y DPMAX (1.8 kg y 20 días, respectivamente), en contraste a las altas estimaciones de $\beta_{1}$; lo anterior puede señalar ciertos problemas de estos modelos para ajustar la parte inicial de la CL.

Los valores promedios para PMAX y PTOTAL fueron 7.8 y $1,660 \mathrm{~kg}$, respectivamente; estos resultados son superiores a los previamente autocorrelation; and c) $\mathrm{DW} \leq 0$ indicates a positive autocorrelation.

No differences in APE, PEV and DW were present between the two analyses run to select the model with the best fit (Table 1). Based on APE and the DW statistic, all the NLM predictions tended to underestimate the analyzed information, with no autocorrelation between residuals. The mixed NLM exhibited the best fit based on the three results in Table 1: a) the residual variances of ANA2 were lower (up to $82 \%$ in the SIK and WOD models) than those estimated in ANA1; b) consequently, the ANA2 $\mathrm{R}^{2}$ values (97\% on average) were higher than those produced by ANA1 (87\% in all), in an interval of 9 to $12 \%$; and C) the $\mathrm{AIC}$ and $\mathrm{BIC}$ criteria conjointly exhibited the best fit in ANA2. As a function of the AIC, BIC and $\mathrm{R}^{2}$ criteria, the best fit within ANA2 was with the WOD model, followed by the SIK and BRO models. With the ANA2 results, estimations were made for IP, DPMAX, PMAX and PTOTAL (Table 1).

The WOD NLM is widely seen to have the best statistical fit when using different selection and hierarchization criteria; it is the most popular model to describe dairy cow LC. Its regression coefficients are associated with different LC components and allow derivation of other partial or total production indicators over time $(7,8,27)$. In one study, the WOD NLM was found to be the most apt of sixteen different NLM in LC for six cross genotypes using different BT:BI proportions(21). This model was also found to be apt, with an ideal fit, for modeling milk production in beef cattle in different sampling schemes $(28,29)$.

In the NLM, $\beta_{1}$ is associated with lactation initial production, $\beta_{2}$ with the ascending phase or peak production, and $\beta_{3}$ with descending rate or persistence. The combination of signs in $\beta_{2}$ and $\beta_{3}$ showed the WOD and WIL models to fit four unimodal curve types(30): 1) standard or typical curve, WOD $+\beta_{2},-\beta_{3}$ and WIL $-\beta_{2},-\beta_{3}$; 2) continuously descending curve (atypical), WOD $-\beta_{2},-\beta_{3}$ and WIL $+\beta_{2},-\beta_{3} ; 3$ ) inverted 
reportados $(5,31,32)$ en bovinos Siboney; además de los reportados por Rodríguez y Ponce de León(19) en otros genotipos producto de las cruzas de Bl con BT; sin embargo, son inferiores a los reportados en bovinos Mambí(33,34).

Los sistemas de producción de bovinos lecheros en condiciones tropicales cálidas dependen de factores relacionados con el animal, ambiente, alimentación y tecnología de producción. En el contexto del animal, la variabilidad en los niveles productivos se puede atribuir al genotipo, en función de la proporción de genes BI y BT que constituyen al individuo $(35,36)$; en el contexto de tecnología, la producción de leche es afectada por la interacción del becerro con la vaca y por el manejo del amamantamiento de la cría(18). La alimentación en los sistemas tropicales se fundamenta en pastoreo de gramíneas forrajeras, y en algunas ocasiones se complementa con leguminosas forrajeras(37); sin embargo, los efectos del ambiente se caracterizan por la prevalencia de parásitos internos y externos, temperaturas y niveles de humedad altos que repercuten en estrés del animal; así como en la calidad y disponibilidad del forraje(1,38). En bovinos Siboney, el modelo de Wood fue el que mejor se ajustó para caracterizar la curva de lactancia a 240 días; presentando una curva continuamente incrementando, con una producción máxima de $7.71 \mathrm{~kg}$ a los 40 días, así como una producción total acumulada de 1,653 kg. Los modelos no lineales mixtos presentaron los mejores ajustes, en función de los criterios de información Akaike y Bayesiano; además de reducir la varianza residual, con aumentos del $11 \%$ en el coeficiente de determinación.

\section{AGRADECIMIENTOS}

Se agradece al Centro de Investigaciones para el Mejoramiento Genético de la Ganadería Tropical (CIMAGT) de la República de Cuba, el proporcionar la información para la realización del presente estudio. standard curve (U), WOD $-\beta_{2},+\beta_{3}$ and WIL $+\beta_{2},+\beta_{3}$; and 4) continuously increasing curve: WOD $+\beta_{2},+\beta_{3}$ and WIL $-\beta_{2},+\beta_{3}$. The standard LC based on the WIL model and the continuously increasing LC based on the WOD model exhibited similar estimations for PMAX and PTOTAL (Figure 1), but differed notably in their estimations of IP and DPMAX (Table 1). In contrast to the high $\beta_{1}$ estimates they produced, both the COB and BRO models generated underestimates for initial lactation points such as IP (1.8 kg) and DPMAX (20 d). This may indicate that these models have certain problems estimating the early portions of the LC.

Average PMAX was $7.8 \mathrm{~kg}$ and average PTOTAL was $1,660 \mathrm{~kg}$, levels higher than previously reported for Siboney cattle $(5,31,32)$, and other $\mathrm{BI} \times$ BT genotypes (19). However, they are lower than reported in Mambí cattle $(33,34)$.

Dairy cattle production systems under warm tropical conditions depend on factors linked to the animal, environment, feeding and production technology. Variability in production at the animal level can be attributed to genotype as a function of the $\mathrm{Bl}: \mathrm{BT}$ proportion in a given individual( 35,36$)$. At the technology level, milk production is affected by the cow/calf interaction and nursing management(18). In tropical systems, feeding is largely based on grazing of forage grasses, occasionally complemented by forage legumes(37). Factors involved in the environment level include prevalence of internal and external parasites, stress caused by high temperatures and rainfall, and forage quality and availability $(1,38)$. In the present results, the Wood model had the best fit for characterizing the lactation curve in Siboney cattle at $240 \mathrm{~d}$. The curve was one of continuous increase with a peak production of $7.71 \mathrm{~kg}$ at $40 \mathrm{~d}$ and a cumulative total production of $1,653 \mathrm{~kg}$. The nonlinear mixed models exhibited the best fits based on the Akaike and Bayesian information criteria, and reduced residual variance, with increases of $11 \%$ in the determination coefficient. 


\section{LITERATURA CITADA}

1. Galukande E, Mulindwa H, Wurzinger M, Roschinsky R, Mwai AO, Sölkner J. Cross-breeding cattle for milk production in the tropics: achievements, challenges and opportunities. Anim Genet Res 2013;52:111-125.

2. López D. New dairy breeds in Cuba. Rev Bras Genet 1989; 12(3):231-239.

3. López D, Ribas M. Formación de nuevas razas lecheras; resultados en Cuba. Rev Cubana Cienc Agríc 1993;27:1-9.

4. Fernández L, Menéndez A, Guerra C. Estudio comparativo de diferentes funciones para el análisis de la curva de lactancia en el genotipo Siboney de Cuba. Rev Cubana Cienc Agríc 2004;38:23-27.

5. Ribas M, Gutiérrez M, Mora M, Évora JC, González S. Comportamiento productivo y reproductivo del Siboney de Cuba en dos localidades. Rev Cubana Cienc Agríc 2004; 38(2): 121-126.

6. Papajcsik IA, Bodero J. Modelling lactation curves of Friesian cows in a subtropical climate. Anim Prod 1988; 47:201-207.

7. Landete-Castillejos T, Gallego L. Technical note: the ability of mathematical models to describe the shape of lactation curves. J Anim Sci 2000; 78:3010-3013.

8. Macciotta NPP, Dimauro D, Rassu SPG, Steri R, Pulina G. The mathematical description of lactation curves in dairy cattle. Ital J Anim Sci 2011; 10:213-224.

9. Quintero JC, Serna JI, Hurtado NA, Rosero NR, CerónMuñoz MF. Modelos matemáticos para curvas de lactancia en ganado lechero. Rev Col Cienc Pecu 2007;20:149-156.

10. Fathi $\mathrm{NMH}$, France J, Odongo NE, Lopez S, Bannink A, Kebreab $\mathrm{E}$. Modelling the lactation curve of dairy cows using the differentials of growth functions. J Agric Sci 2008; 146: 633-641.

11. Bates DM, Watts DG. Nonlinear regression: iterative estimation and linear approximations. New York, USA: John Wiley \& Sons, Inc.; 1988.

12. Littell RC, Milliken GA, Stroup WW, Wolfinger RD, Schabenberger O. SAS System for mixed models. 2nd ed. North Caroline, USA: SAS Institute Inc.; 2006.

13. Ching-Fan S. Using SAS PROC NLMIXED to fit item response theory models. Behavior Res Meth 2005; 37:202-218.

14. Pinheiro JC, Bate DM. Approximations to the log likelihood function in the nonlinear mixed effects model. J Computer Graph Stat 1995; 4:12-35.

15. Wolfinger RD. Fitting nonlinear mixed models with the new NLMIXED procedure. Proc 24th Annual SAS Users Group International Conference. 1999:278-284.

16. Ferris TA, Mao IL, Anderson CR. Selecting for lactation curve and milk yield in dairy cattle. J Dairy Sci 1985;68: 14381448.

17. Madalena FE. A note on the effect of variation of lactation length on the efficiency of tropical cattle selection for milk yield. Theor Appl Genet 1988;76:830-834.

18. Osorio-Arce MM, Segura-Correa JC. Factores que afectan la curva de lactancia de vacas Bos taurus $\mathrm{x}$ Bos indicus en un sistema de doble propósito en el trópico húmedo de Tabasco, México. Téc Pecu Méx 2005;43(1):127-137.

19. Rodríguez $\mathrm{Y}$, Ponce de León R. Caracterización de la producción lechera (1986 hasta 2007) de los genotipos

\section{ACKNOWLEDGEMENTS}

Thanks are due to the Centro de Investigaciones para el Mejoramiento Genético de la Ganadería Tropical (CIMAGT) of the Republic of Cuba for providing the data on which this study is based.

End of english version

vacunos Cebú lechero Cubano (3/4 Cebú: 1/4 Holstein) y sus mestizos. Rev Cubana Cienc Agríc 2011;45(3):231-236.

20. IMRC. Instituto de Meteorología de la República de Cuba. Disponible: http://www. met.inf.cu/. Consultado 4 abril, 2014.

21. García-Muñiz JG, Martínez-González EG, Núñez-Domínguez $\mathrm{R}$, Ramírez-Valverde R, López-Ordaz R, Ruiz-Flores A. Comparación de ecuaciones para ajustar curvas de lactancia en bovinos. Rev Cientí FCV-LUZ 2008; 18(2):160-169.

22. Cobuci JA, Euclydes RF, Pereira CS, Ameida TR, Costa CN, Lopes PS. Persistência na lactação - uma revisão. Arch Latinoam Prod Anim 2003; 11(3): 163-173.

23. SAS. SAS/STAT User's Guide (Release 9.0). Cary NC, USA: SAS Inst. Inc. 2005.

24. Motulsky $\mathrm{H}$, Christopoulos A. Fitting models to biological data using linear and nonlinear regression. A practical guide to curve fitting. Graph Pad Software Inc; 2003.

25. Posada SL, Rosero NR. Comparación de modelos matemáticos: una aplicación en la evaluación de alimentos para animales. Rev Col Cienc Pecu 2007;20:141-148.

26. Torres V, Barbosa I, Meyer R, Noda A, Sarduy L. Criterios de bondad de ajuste en la selección de modelos no lineales en la descripción de comportamientos biológicos. Rev Cubana Cienc Agríc 2012; 46:345-350.

27. Scott TA, Yandell B, Zepeda L, Shaver RD, Smith TR. Use of lactation curves for analysis of milk production data. J Dairy Sci 1996; 79:1885-1894.

28. Domingues SAM, Marques de Almeida JC, Cruz dos Santos VA, Peixoto FP, Cardoso AV. Modeling lactation curves of Barrosa beef cattle with Woods model. Ital J Anim Sci 2010; 9: 244-247.

29. Korkmaz M, Üçkardes F, Kaygisiz A. Comparison of Wood, Gaines, Parabolic, Hayashi, Dhanno and polynomial models for lactation season curve of Simmental cows. J Anim \& Plant Sci 2011;21:448-458.

30. Macciotta NPP, Vicario D, Cappio-Borlino A. Detection of different shapes of lactation curve for milk yield in dairy cattle by empirical mathematical models. J Dairy Sci 2005; 88:1178-1191.

31. Hernández R, Ponce P. Caracterización de la curva de lactancia y componentes lácteos del genotipo Siboney de Cuba en una granja ganadera de la provincia de La Habana. Rev Cientí FCV-LUZ 2008; 18(3): 291-295.

32. Suárez MA, Zubizarreta I, Pérez T. Interacción genotipo ambiente en ganado bovino Siboney de Cuba. Livest Res Rural Develop 2009;21:31-42. 
33. Hernández A, Ponce de León R, Gutiérrez M, García SM, García R, Mora M, Guzmán G. Efectos ambientales en la producción lechera de la raza bovina Mambí de Cuba. Rev Cubana Cienc Agríc 2005;39(4):533-542.

34. Hernández A, Ponce de León R, García SM, Guzmán G, Mora M. Evaluación genética del bovino lechero Mambí de Cuba. Rev Cubana Cienc Agríc 2011;45(4):355-359.

35. McDowell RE, Wilk JC, Talbott CW. Economic viability of crosses of Bos taurus and Bos indicus for dairying in warm climates. J Dairy Sci 1996; 79:1292-1303.
36. López OR, García CR, García MJ G, Ramírez VR. Producción de leche de vacas con diferente porcentaje de genes Bos taurus en el trópico mexicano. Téc Pecu Méx 2009; 47(4): 435-448.

37. Senra AF. Principales sistemas de pastoreo para la producción de leche y su adecuación a las condiciones de Cuba. Rev Cubana Cienc Agríc 2005; 39:415-425.

38. Burrow HM. Importance of adaptation and genotype $x$ environment interactions in tropical beef breeding systems. Animal 2012;6:729-740. 